\title{
POTENSI EKSTRAK DAUN SAMBILOTO SEBAGAI OBAT ANTIDIABETES
}

\author{
Baridi Adlan Saputra \\ Fakultas Kedoktern, Universitas Lampung, Jl. Prof. DR. Ir. Sumatri Brojonegoro No.1, Gedong Meneng, \\ Kec. Rajabasa, Kota Bandar Lampung, Lampung, Indonesia 35145 \\ baridiadlansaputra@gmail.com (+6281278289846)
}

\begin{abstract}
ABSTRAK
Banyak orang yang memutuskan untuk mencari oba alternatif untuk penyakit diabetes melitus yang lebih minim akan efek samping seperti tanaman herbal. Salah satu tumbuhan yang sering dijadikan sebagai obat alternatif untuk diabetes adalah daun sambiloto. Tanaman sambiloto memiliki beberapa kandungan yang bersifat antidiabetes. Tujuan dilakukannya literature review ini adalah untuk mengetahui potensi dari ekstrak daun sambiloto sebagai obat antidiabetes. Sumber referensi yang digunakan untuk menyusun tulisan ini meliputi 20 artikel yang didapat dengan melakukan literature searching di Sumber NCBI dan google schoolar yang dipublikasikan dalam rentang tahun 2000-2021. Literature sarching tersebut dilakukan dengan menggunakan kata kunci Andrographis paniculata, antidiabetic dan juga filter berupa rentang publikasi tahun 2000-2021. Hasil yang ditemukan dari literature searching ini adalah 1036 artikel yang kemudian dipilih 20 artikel berdasarkan informasi yang dibutuhkan. Hasil literature review ini berupa ekstrak daun sambiloto memiliki potensi yang cukup baik sebagai obat antidiabetes karena mengandung beberapa senyawa seperti andrografolid, , andrografin, flavonoid, penikulin dan senyawa-senyawa lainnya yang juga dapat bertindak sebagai antidiabetes.
\end{abstract}

Kata kunci: andrographis paniculata; antidiabetic

\section{THERAPY FOR THYPHOID FEVER WITHOUT COMPLICATION}

\begin{abstract}
Diabetes is a disease that requires sufferers to take antidiabetic drugs continuously for life. Because of this, many people decide to look for alternative drugs that are less likely to side effects, such as herbal plants. One of the plants that is often used as an alternative medicine for diabetes is bitter leaf. Sambiloto plants have several ingredients that are antidiabetic. The purpose of this literature review is to determine the potential of sambiloto leaf extract as an antidiabetic drug. Reference sources used to compile this paper include 20 articles obtained by doing literature searching on NCBI and Google Schoolar Sources which were published in the 2000-2021 range. The literature sarching was carried out using the keywords Andrographis paniculata, antidiabetic and also filters in the form of publication ranges from 2000-2021. The results found from this literature searching were 1036 articles, then 20 articles were selected based on the required information. The results of this literature review in the form of sambiloto leaf extract have quite good potential as an antidiabetic drug because it contains several compounds such as andrographolid, andrographin, flavonoids, peniculin and other compounds which can also act as antidiabetic.
\end{abstract}

Keywords: andrographis paniculata; antidiabetic

PENDAHULUAN

Diabetes melitus atau yang biasa disingkat dengan DM merupakan suatu penyakit gangguan kronis yang mengganggu metabolisme protein, lemak, dan juga karbohidrat. Diabetes 
melitus (DM) dapat digambarkan sebagai peningkatan kadar glukosa darah pada saat setelah semua jenis makan (International diabetes federation, 2003). Diabetes melitus adalah penyakit yang terbanyak dan menjadi suatu masalah utama dari penyakit metabolik yang ada di dunia (American Diabetes Association, 2018). Kementrian kesehatan RI dalam Riset Kesehatan Dasar (Riskesdas) 2018 memperkirakan bahwa jumlah dari penderita DM di Indonesia pdengan usia di atas 15 tahun adalah sebanyak 8,5\% dari penduduk Indonesia, atau sekitar 14 juta jiwa yang menderita diabetes melitus. Diabandingkan dengan data yang didapat pada Riskesdas tahun 2013 prevalensi ini meningkat sekitar $2,6 \%$. Sedangkan jumlah yang menderita DM dan terdiagnosis di Provinsi Lampung adalah sebanyak 31.462 jiwa (Kementrian Kesehatan RI, 2018).

Diabetes melitus (DM) merupakan penyakit yang mengakibatkan penderitanya diharuskan untuk mengkonsumsi obat anti diabetes secara terus-menerus seumur hidupnya. Penggunaan dari obat anti diabetes secara terus- menerus akan menimbulkan efek samping terhadap tubuh penderita, dan juga akan berpengaruh pada psikologi penderita. Keadaan tersebut mendorong penderita DM untuk mencari pengobatan alternatif lain yang cukup murah, berkhasiat sama dengan ibat anti diabetes, dan tidak memiliki efek samping, dan juga agar mudah didapat (Ismarani, 2013).

Terapi konvensional pada DM yang digunakan untuk menurunkan kadar dari glukosa darah. Beberapa contoh terapi konvensional DM adalah sulfonilurea, metformin dan insulin pada umunya terapi-terapi dibatasi oleh efek samping gastrointestinal, terjadinya hipoglikemia dan adanya peningkatan berat badan. Penggunaan obat golongan analog glucagon-like-peptide-1 (GLP-1) sering dibatasi oleh dokter karena dapat mengakibatkan penurunan berat badan pada pasien DM. Selain itu, analog GLP-1 memiliki efek samping pada gastrointestinal. Peningkatan prevalensi diabetes melitus, keterbatasaan terapi konvensional, dan efek samping yang ditimbulkan membutuhkan terapi baru yang dapat menjadi alternatif untuk mengurangi morbiditas dan mortalitas akibat diabetes melitus (Luman, 2015).

Masyarakat di Indonesia sudah lama mengenal dan memanfaatkan tanaman herbal berkhasiat sebagai obat dalam penanggulangan masalah kesehatan. Pengetahuan tentang tanaman herbal yang berkhasiat sebagai obat berdasarkan pada keterampilan dan pengalaman yang diwariskan secara turun temurun dari generasi satu ke generasi berikutnya (Oktora et al., 2006). Saat ini telah banyak obat tradisional yang digunakan oleh masyrakat Indonesia sebagai obat antidiabetes untuk menurunkan kadar glukosa di dalam darah. Salah satu obat tradisional yang telah diteliti memiliki efek antidiabetik adalah herbal sambiloto (Andrographis paniculata). Daun sambiloto memiliki kandungan orthosiphon glukosa, minyak atsiri, saponin, polifenol, flavonoid, sapofonin, garam kalium dan myonositol (Yulinah et al, 2001)

Sambiloto atau Andrographis paniculata merupakan salah satu tanaman yang ada di Indonesia yang cukup banyak digunakan sebagai obat tradisional antidiabetes dimasyarakat. Tanaman sambiloto ini mengandung diterpen lakton yang merupakan suatu 
senyawa yang terdiri dari neoandrografolid, andrografolid (zat pahit), 14-deoksiandrografolid, dan senyawa 14-deoksi-11oksoandrografolid. Andrografolid merupakan senyawa yang paling aktif dibandingkan dengan senyawa yang lainnya (Niranjan et al, 2010).

Hasil dari penelitian sebelumnya daun sambiloto merupakan salah satu jenis tanaman herbal yang telah banyak diteliti dan terbukti dapat mampu menurunkan kadar glukosa dalam darah. Kandungan utama dari herbal sambiloto adalah andrografolid, zat ini dapat meningkatkan aktivitas penggunaan glukosa otot pada tikus diabetes yang diinduksi dengan streptozotosin (STZ) melalui stimulasi glucose transporter-4 atau GLUT4 sehingga dapat menurunkan kadar glukosa darah plasma pada tikus (Yulinah et al, 2001).

Tujuan penulisan literature review ini adalah untuk mengetahui potensi dari ekstrak daun sambiloto sebagai obat antidiabetes. Literature review ini perlu dilakukan agar memudahkan pembaca untuk mengetahui informasi terkait potensi dari ekstrak herbal daun sambiloto sebagai anti diabetes

\section{METODE}

Penulisan artikel ini menggunakan metode literature review. Tulisan ini terbentuk atas informasi yang didapat dari 20 artikel dari jurnal internasional dan nasional yang dipublikasikan dalam rentang tahun 2000-2021. Referensi yang digunakan didapat dengan melakukan literature searching dari database NCBI dan google scholar dengan kata kunci Andrographis paniculata; antidiabetes dan filter berupa rentang publikasi tahun 20002021. Jumalah artikel yang ditemukan pada literature searching ini adalah sebanyak 1036 artikel yang kemudian dipilih 20 artikel berdasarkan informasi yang dibutuhkan. Artikel yang sudah dipilih kemudian dianalisis dengan metode systemic literature review yang mencakup aktivitas pengumpulan, evaluasi, dan pengembangan penelitian dengan fokus tertentu.

\section{HASIL}

Sambiloto (Andrographis paniculata) dikenal dengan sebutan King of Bitters yang merupakan tanaman asli India dan Cina. Sambiloto termasuk dalam jenis tumbuhan famili Acanthaceae yang telah digunakan selama beberapa abad di Asia dalam sistem pengobatan. Sambiloto dapat dikembangbiakkan dengan biji atau pun stek batang dan mampu tumbuh di semua jenis tanah dan iklim mulai dari dataran pantai, dataran rendah hingga dataran tinggi (Illah et al, 2014). Tanaman Herba sambiloto (Andrographis paniculata) adalah salah satu tnaman yang digunakan sebagai bahan obat tradisional yang cukup banyak dipakai oleh masyarakat Indonesia. (Yulinah et al., 2001).

Masyarakat indonesia menggunakan herba sambiloto sebagai obat diuretika dan untuk antipiretika, sedangkan sumber lain mengemukakan bahwa tanaman herba sambiloto yang dikombinasikan dengan tanaman kumis kucing (Orthosiphon stamineus) diindikasikan dapat berguna sebagai obat antidiabetes (Heyne, 1980). Pada penelitian sebelumnya dimana dilakukan pengamatan terhadap efek kombinasi dari ekstrak herbal sambiloto yang terpurifikasi dan ekstrak herbal tanaman pegagan terhadap translokasi dari protein GLUT-4 yangg dilakukan pada tikus model diabetes melitus tipe 2 yang resisten terhadap insulin, hasil 
penelitian ini menunjukkan bahwa terdapat pengaruh antidiabetes pada penggunaan ekstrak sambiloto tersebut (Lindawati dkk, 2014).

Penelitian lain yang menggunakan ekstrak herbal daun sambiloto dengan dosis $1.5 \mathrm{mg} / \mathrm{kg}$ menunujukan hasil yang bisa menurunkan konsentrasi plasma glukosa darah tikus yang telah diinduksi dengan streptozotocin. Kandungan ekstrak daun sambiloto berupa Andrografolid dapat mengakibtakan terjadinya peningkatkan penggunaan dari glukosa darah sehingga terjadi penurunan kadar glukosa darah pada tikus model diabetes yang telah diinsuksi dengan streptozotocin (Yu dkk, 2008).

Penelitian lain yang juga membuktikan adanya aktivitas antidiabetes oleh ekstrak daun sambiloto. Pada penelitian ysng menggunakan metode pre test-post test control group design ini, pemberian ekstarak etanol daun sambiloto selama 14 hari dapat menurunkan kadar glukosa darah tikus putih diabetes yang diinduksi dengan streptozotocin (Aulia, 2021).

\section{PEMBAHASAN}

Sambiloto atau Andrographis paniculata atau dalam taksonom tumbuhan dapat diklasifikasikan sebagai bagian dari famili Acanthaceae yang ada daerah tropis seperti Indonesia. Sambiloto adalah salah satu tumbuhan yang cukup banyak digunakan oleh manusia untuk formulasi pada obat-obatan (Radha et al., 2011). Sambiloto memiliki banyak aktivitas farmakologi seperti antipiretik, antiinflamasi, anti-hiperglisemik, antiviral, antioksidan, dan antidiabetik (Adha et al, 2019). Ekstrak dari daun sambiloto memiliki aktivitas antidiabetes dikarena tanaman ini mengandung senyawa andrografolid. Senyawa androgrofolid merupakan senyawa yang dapat mengakibatkan penggunaan dari glukosa dalam otot tikus yang telah diinduksi dan menderita diabetes melalui proses stimulasi transporter GLUT-4. Senyawa Andrografolid dapat menyebabkan terjadinya peningkatan jumlah ekspresi mRNA dan kadar dari protein GLUT-4 yang menembus sel (Yu dkk, 2008).

Pada penelitian sebelumnya menunjukkan ekstrak daun sambiloto dan senyawa andrografolid yang terkandung didalamnya secara signifikan dapat menurunkan kadar dari glukosa darah, LDL dan trigliserida dibandingkan dengan kelompok kontrol. Dapat disimpulkan bahwa ekstrak dari daun sambiloto dan senyawa andrografolid dapat memberikan efek hipoglikemik dan hipolipidemik pada tikus uji (Nugroho et al, 2013)

Ekstrak etanol daun sambiloto dapat menurunkan kadar glukosa dan menurunkan kadar kolesterol, asam lemak bebas, dan trigliserida dengan dengan cara meningkatkan kadar dari glutation S-transferase (GST), glutation reduktase (GR) dan glutation $S$ hidroksilase (GSH) hati sehingga dapat berfungsi sebagai antioksidatif; menekan glikogenesis dan gluconeogenesis, meningkatkan glikogenesis dan glikolisis serta meningkatkan sensitivitas insulin pada tikus model resisten insulin yang telah diinduksi dengan streptozotosin dan diet lemak (Subramanian et al, 2008).

Ekstrak daun sambiloto juga dapat merangsang pelepasan insulin dan menghambat absorbsi glukosa melalui penghambatan enzim alfaglukosidase dan alfa-amilase (Subramanian et al, 2008). Zat lain yang terkandung dalam 
sambiloto yaitu flavonoid berperan secara signifikan meningkatkan aktivitas antioksidan Senyawa bioaktif flavonoid telah dibuktikan dapat menginduksi terjadinya regenerasi sel beta pankreas yang rusak. Efek antioksidan yang terdapat pada flavonoid menyebabkan terjadinya perbaikan yang bermakna pada sel beta pulau Langerhans pada tikus diabetes (Abdelmoaty dkk, 2010). Kandungan flavonoid pada sambiloto seperti 5hidroksi-2'7,8-trimetoksiflavon,2',5dihidroksi-7,8 dimetoksiflavon, mono0-metilwithin, 5- hidroksi-2',3',7,8 tetrametoksiflavon, 3,4dicaffeoylquinic, apigenin-7,4dimetileter. Kandungan lain yang juga terkandung dalam sambiloto adalah androgfrafin, panikulida A,B,dan C, androgfrafin, dan senyawa penikulin (Chao et al, 2010).

Terjadinya penurunan pada kadar glukosa darah yang diakibatkan oleh ekstrak daun sambiloto dikarenakan dipicu oleh senyawa-senyawa aktif atau senyawa bioaktif di dalam ekstrak daun sambiloto seperti, alkaloid, tanin polifenol, dan flavonoid yang merupakan antioksidan sehingga dapat menurunkan kejadian stress oksidatif yang dapat mencegah nekrosis sel beta pankreas (Suryani et al, 2013).

Senyawa golongan flavonoid merupakan senyawa polifenol dengan susunan C6-C3-C6 sebagai kerangka dasar. Senyawa flavonoid mempunyai tipe yang sangat beragam dan terdapat dalam bentuk senyawa bebas sebagai aglikon dan juga terdapat sebagai senyawa terikat dalam bentuk glikosida. Aglikon polimetoksi bersifat non polar, aglikon polihidroksi bersifat semi polar, sedangkan glikosida flavonoid bersifat polar karena mengandung sejumlah gugus gula dan hidroksil. Oleh karena itu senyawa golongan flavonoid dapat tertarik dalam pelarut etanol yang bersifat universal. Senyawa flavonoid dilaporkan memiliki berbagai aktivitas antibakteri, antiulser, antidepresan (Yi et al, 2010).

Senyawa flavonoid bersifat sebagai antioksidan yang berarti dapat menurunkan kadar radikal bebas dan menghambat induksi mediator inflamasi yang berpotensi menyebabkan kerusakan sel pada pankreas. Flavonoid dapat pula menstimulasi pembentukan glutation stimulating hormone (GSH) yang merupakan salah satu protektor endogen terhadap radikal bebas dalam tubuh (Arifin et al, 2014).

\section{SIMPULAN}

Ekstrak daun Sambiloto (Andrographis paniculata) mengandung banyak senyawa didalamnya, daiantaranya andrografolid, , andrografin, flavonoid, penikulin dan senyawa-senyawa lainnya yang juga dapat bertindak sebagai antidiabetes. Sambiloto memiliki potensi yang cukup baik sebagai bahan baku obat dan memiliki potensi yang masih sangat banyak dalam pengembangan obat-obatan antidiabetes.

\section{DAFTAR PUSTAKA}

Abdelmoaty MA, Ibrahim MA, Ahmed NS, Abdelaziz MA. 2010. Confirmatory Studies on the Antioxidant and Antidiabetic Effect of Quercetin in Rats. Indian Journal of Clinical Biochemis try. 25(2):188-92.

Adha, S. A., Febriyanti, R. M., \& Milanda, T. (2019). Review: Potensi Sambiloto Sebagai Obat Antidiabetes Berbasis Herbal a Review: Potential of Sambiloto As Herbal Based Antidiabetic 
Medicine. Medical Sains, 4(1), 712.

DOI: http://dx.doi.org/10.37874/ ms.v4i1.118

American Diabetes Association. 2018. Classification and diagnosis of diabetes mellitus. Diabetes Care. 41(Suppl 1):S13-S27.

Arifin, R., Bangsawan, P. I., \& Andriani. (2014). Efek Hepatoprotektor Ekstrak Etanol Lidah Buaya (Aloe vera) Terhadap Aktivitas Enzim Alanin Aminotransferase (ALT) dalam Plasma Rattus norvegicus Jantan Galur Wistar yang diinduksi Parasetamol. Faukultas Kedokteran . Universitas Tanjungpura, $\quad 9-10$. https://jurnal.untan.ac.id/index.ph p/jfk/article/viewFile/7397/7544

Aulia, R. (2021). Efek pemberian ekstrak daun sambiloto (andrographis paniculata) terhadap penurunan glukosa darah pada tikus putih (rattus norvegicus) yang diinduksi streptozotocin. skripsi fakultas kedokteran universitas lampung.

Chao, W. W., \& Lin, B. F. (2010). Isolation and identification of bioactive compounds in Andrographis paniculata (Chuanxinlian). Chinese Medicine, 5, 1-15. https://doi.org/10.1186/17498546-5-17

Heyne, K., "Tumbuhan Berguna Indonesia" (Terjemahan), Balai Penelitian Kehutanan, Dep. Kehutanan, Jakarta, 1756 (1987).

Illah, Z. A., Ratnani, D. R., Suwardiono, Hartati, I. (2014). Ekstraksi Hidrotopi dengan

$\begin{array}{lrr}\text { Magnetic Striret } & \begin{array}{r}\text { untuk } \\ \text { Mendapatkan }\end{array} \\ \text { Senyawa } \\ \text { Andrografolid dari } & \text { Tanaman } \\ \text { Sambiloto. Jurnal Momentum. } \\ \text { 10(1):38-42. } \\ \text { https://ojs2.unwahas.ac.id/index.p } \\ \text { hp/MOMENTUM/article/view/96 } \\ 2\end{array}$

Ismarani. (2013). Kajian Persepsi Konsumen Terhadap Penggunaan Obat Herbal ( Kasus di Unisma Bekasi). CEFAR: Jurnal Agribisnis Dan Pengembangan Wilayah, $\quad 4(2)(2), 52-63$. http://jurnal.unismabekasi.ac.id/in dex.php/cefars/article/view/58

Kemenkes. 2018. Riset kesehatan dasar. Jakarta: Badan Penelitian dan Pengembangan Kemenkes RI

Linson, M., Bresnan, M., Eraklis, A., \& Shapiro, F. (1981). Acute gastric volvulus following harrington rod instrumentation in a patient with werdnig-hoffman disease. Spine, 6(5), 522-523. https://doi.org/10.1097/00007632198109000-00015

Luman, A. (2015). Peran Inhibitor Sodium pada Terapi Diabetes Melitus. Cermin Dunia Kedokteran (CDK), 42(7), 498503.

http://www.cdkjournal.com/index. php/CDK/article/view/985

Niranjan, A., Tewari, S. K., \& Lehri, A. (2010). Biological activities of Kalmegh (Andrographis paniculata Nees) and its active principles-A review. Indian Journal of Natural Products and Resources, 1(2), 125-135. http://hdl.handle.net/123456789/9 $\underline{819}$

Nugroho, A. E., Lindawati, N. Y., 
Herlyanti, K., Widyastuti, L., \& Pramono, S. (2013). Anti-diabetic effect of a combination of andrographolide-enriched extract of andrographis paniculata (Burm f.) Nees and asiaticoside-enriched extract of Centella asiatica L. in high fructose-fat fed rats. Indian Journal of Experimental Biology, 51(12), 1101-1108. http://hdl.handle.net/123456789/2 $\underline{4549}$

Oktora, L., Kumala, R., Staf, S., Program, P., Farmasi, S., \& Pendahuluan, U. J. (2006). Pemanfaatan Obat Tradisional Dengan Pertimbangan Manfaat Dan Keamanannya. Majalah Ilmu Kefarmasian, III(1), 1-7. http://psr.ui.ac.id/index.php/journ al/article/view/3394

Radha, R., Sermakkani, M., Thangapandian, V. (2011). Evaluation of phytochemical and antimicrobial activity of Andrographis paniculata nees (Acanthaceae) aerial parts. International Journal Of Pharmacy \& Life Sciences 2 (2) : 09767126.

Subramanian, R., Asmawi, M. Z., \& Sadikun, A. (2008). In vitro $\alpha$ glucosidase and $\alpha$-amylase enzyme inhibitory effects of Andrographis paniculata extract and andrographolide. Acta Biochimica Polonica, 55(2), 391398.

https://doi.org/10.18388/abp.2008 _3087

Suryani, N., Endang, M., Aulani, A., (2013). Pengaruh Ekstrak Etanol Biji Mahoni terhadap Peningkatan Kadar Insulin, Penurunan Ekspresi TNF- $\alpha$ \& Perbaikan
Jaringan Pankreas Tikus Diabetes. Jurnal Kedokteran Brawijaya. 27(3): 55-9.

DOI: http://dx.doi.org/10.21776/u b.jkb.2013.027.03.3

Yi, L., Li, C., Zhan, X., Cui, C., Xiao, F., Zhou, L., dan Xie, Y. (2010). Involvement of Monoaminergic System in Antidepressant-like Effect of Flavonoids Naringenin in Mice. Prog Neuropsychopharmacol Biol Psychiatry, Vol. 34: 1223-1228. DOI: http://dx.doi.org/10.37874/ $\underline{\text { ms.v4i1.118 }}$

Yu BC, Chang CK, Su CF, Cheng JT. (2008). Mediation of $\beta$-endorphin in andrographolide induced plasma glucoselowering action in type I diabetes-like animals. Naunyn-Schmiedeberg's Arch Pharmacol. 377(1) : 529-40. https://doi.org/10.1007/s00210007-0240-0

Yulinah, E., Sukrasno, S., \& Fitri, M. A. (2001). Aktivitas Antidiabetika Ekstrak Etanol Herba Sambiloto. Jms, 6(1), 13-20. https://www.researchgate.net/prof ile/Elin_Sukandar/publication/277 051289_Aktivitas_Antidiabetika_ Ekstrak_Etanol_Herba_Sambiloto _Andrographis_paniculata_Nees_ Acanthaceae/links/55d4acaa08ae4 3dd17de4764.pdf 
Jurnal Penelitian Perawat Profesional, Volume 3 No 2 Hal 253 - 260, Mei 2021 Global Health Science Group 